\title{
Beta Glucuronidase Measurement
}

National Cancer Institute

\section{Source}

National Cancer Institute. Beta Glucuronidase Measurement. NCI Thesaurus. Code C80170.

The determination of the amount of beta glucuronidase present in a sample. 